\title{
Factors Determining the Technical Efficiency of Rural Households in Dak Lak Province of Vietnam
}

- Le Duc Niem ${ }^{l}$

\begin{abstract}
Most agricultural programs generally aim at helping poor households.They become the cornerstone to enhance some self-employed activities. Thus, identifying factors which are significant to extend their existing skills and incomegenerating opportunities is considered an important step in designing a program to improve performance of rural households. This paper derives some statistically significant determinants of the technical efficiency of rural households and gives some implications for poverty reduction efforts in rural areas of Ea H'leo district, Daklak province.
\end{abstract}

Keywords: score estimation, agricultural production, socio-economic status, econometrical model and chow-test

\section{Introduction}

Previous studies have mainly focused on the nation's investment policies or on the effectiveness and impacts of the poverty alleviation programs on the income of the poor (Balisacan, Pernia, and Estrada, 2003; Hien, 2006). Especially, some authors focused on the relationship between the economic growth and poverty and argue that poverty reduction efforts involve nothing more than creating an environment conducive to rapid economic growth. However, recent studies show that economic growth explains a lot but not all about poverty (Balisacan, Pernia, and Estrada, 2003).

Actually, some household-level analyses are also conducted. For example, some studies have been carried out to focus on the economics of resource issues and farm specific factors affecting production efficiency e.g. ( Nchare, 2007). Socio-economic factors such as ethnicity, income status, labor, fertilizers and pesticides and resources such as irrigation water, and land are proven to play vital roles in modern-day economies and society as they relate to agricultural production and thus relate to the household income. Each of these contributors has particular characteristics that can be quantified and appropriately applied in policy design for rural areas. On the other hand, various studies focus on micro-credit, small loans given to the rural poor, as a main tool to fight against poverty. However, evidences of micro-credits effects on poverty alleviation are ambiguous. Pitt and Khandker (1998) have used the initial World Bank-BIDS survey data from Bangladesh, collected in 1991 and 1992, to test the impact of microcredit on various measures of poverty such as household consumption expenditure and children's schooling. In short, Pitt and

1 Dr. Niem is a Dean of Faculty of Economics, Tay Nguyen University, Vietnam 
Khandker (1998) have found that micro-credit has a significant impact on household outcomes and that women's borrowing has a stronger positive effect on these outcomes compared with the ones borrowed by men. McKernan (2002) has used the 1991 and 1992 World Bank-BIDS data to study self-employment profits and reported that participation in micro-credit programs increased monthly profits. Banerjeey et al (2009) have showed mixed results that micro-credit created no effect on household expenditure, gender equality, education or health, but the number of new businesses increased. Dean Karlan (2012) says that microcredit has not had a positive impact on gender relationships, did not alleviate poverty and has led many borrowers into a debt trap.

Different from previous papers, this paper aims at identifying main factors that determine rural households' technical efficiency which is used as a proxy for the households' economic efficiency. As a dummy variable for credit size are employed as a factor in our model and we also check if small size of loans is effective in the improvement of households' efficiency or not.

\section{The Model}

\subsection{Technical efficient score estimation}

Generally, economic efficiency consists of technical efficiency and allocative efficiency. While, technical efficiency refers to the ability of the production unit to maximize its output for a given vector of inputs or minimizing its inputs for a given vector of outputs, allocative efficiency reflects the ability to choose optimal proportions of inputs given their relative prices. Based on this theory, both parametric and non-parametric approaches for measuring efficiency have been proposed and applied (Battese \& Coelli 1995; Seyoum, Battese, \& Fleming, 1998; Charnes, Cooper, \& Rhodes, 1978; McDonald, 2009).

Data Envelopment Analysis (DEA) is a non-parametric methodology, firstly introduced by Charnes et al., (1978) to evaluate the relative efficiencies of comparable decision-making units (DMUs). This method has been widely applied in variety of sectors such as agricultural economics, financial management, and etc. (Cinemre et al., 2006; Smith, 1990). The DEA model proposed by Charnes, Cooper and Rhodes in 1978 (CCR) revealed that measure of the relative efficiency score of any decision making unit can be obtained as maximum of a ratio of weighted outputs to weighted inputs subject to the similar ratios of every DMU are less than or equal to 1 . According to CCR, the efficient score estimation method can be written in short as follows:

\section{$\operatorname{Max} y_{K}$}

Subject to

$$
\begin{aligned}
& \sum_{k=1}^{K} y^{k} \lambda^{k} \geq y \\
& \sum_{k=1}^{K} x_{n}^{k} \lambda^{k} \leq x_{n}^{0}
\end{aligned}
$$




$$
\begin{aligned}
& \sum_{k=1}^{K} \lambda^{k}=1 \\
& \lambda^{k} \geq 0 \quad k=1,2, \ldots, K
\end{aligned}
$$

Where $y$ is the best output, $y^{k}$ is output of $\mathrm{k}^{\text {th }}$ household, $x_{n}^{k}$ is $\mathrm{n}^{\text {th }}$ input used in the $\mathrm{k}^{\text {th }}$ household, $x_{n}^{0}$ is input of $\mathrm{n}^{\text {th }}$ household that we want to measure its efficiency and $\lambda^{k}$ is a weight assigned to $\mathrm{k}^{\text {th }}$ household to form a convex combination of inputs. The technical score is measured by a ratio of $y^{0} / y$.

\subsection{Data sources and methodology for data collection}

The major types of data used in this study are agricultural production and socio-economic status of households in rural area in the Ea Hleo district, Dak Lak province. Information and data on farming production are collected by using questionnaire. For the econometric model, explanatory variables including income diversification, scale of land under cultivation, ethnicity, and age of household heads are obtained and calculated from the data. The market prices of outputs and inputs corresponding to monthly data are applied to convert physical units to monetary values. Paddy rice and coffee production data of each household are collected for crop year 2010/2011 by the interviewee recall method.

The sample size for this study is 166 households randomly selected to be the representative of economic status and ethnicity perspectives in Ea Hleo district. The selection of households is based on stratified method. Regarding the economic status, there are 2 strata which are poor households and non-poor households. For the ethnicity representation, 2 strata considered are majority group (Kinh group) and other groups as the second stratum. These types of information associated with lists of households are provided by commune people's committees.

\section{Data Analysis and Presentation}

\subsection{Data specification}

Summary statistics regarding key variables for the DEA estimation and econometric model are described in Table 1. Error during survey procedure and data measurement may be a problem for any empirical study, therefore testing for the robustness of the models is necessary. In this study, common statistical tests are performed. 
Table 1: Summary statistics of key variables

\begin{tabular}{|l|l|r|r|r|r|}
\hline Variable & N & Mean & Std Dev & Minimum & Maximum \\
\hline Income (million VND) & 166 & 76.42 & 69.20 & 1.56 & 520.00 \\
\hline Cost (million VND) & 166 & 15.12 & 16.00 & 0.00 & 113.00 \\
\hline Land (hectares) & 166 & 0.77 & 0.40 & 0.20 & 2.50 \\
\hline Labor (man-day) & 166 & 126.99 & 97.93 & 10.00 & 660.00 \\
\hline Technical Efficiency & 166 & 0.64 & 0.24 & 0.06 & 1.00 \\
\hline Credit loan per year (million VND) & 166 & 12.61 & 10.32 & 0.00 & 70.00 \\
\hline Simpson Index 2 & 166 & 0.60 & 0.26 & 0.10 & 1.00 \\
\hline Ethnicity (1 for majority, 0 for otherwise) & 166 & 0.65 & 0.48 & 0.00 & 1.00 \\
\hline Age (year) & 166 & 41.73 & 10.81 & 18.00 & 73.00 \\
\hline
\end{tabular}

Firstly, Chow test is conducted to determine whether pooling data by different economic status (poor households and non-poor households) of households exists.

The result of Chow test suggests that it is appropriate to combine these two groups to be one model for investigating factors affecting technical efficiency. ${ }^{3}$

Secondly, a test is conducted to check if there is multi-colinearity problems associated with the econometric model. Both correlation matrix and variance inflation factor (VIF) are investigated. This diagnostic method measures how much the variance of a regression coefficient is inflated by the fact that other independent variables contain the similar information as the variable in question. Large values of this diagnostic method indicate signs of serious multi-collinearity. The results show that multi-collinearity is not a problem for this data set ${ }^{4}$ as VIFs are less than 10 .

\subsection{Econometric model}

The overall mean of technical efficiency for farming in the rural area in Dak Lak are estimated to be 0.64 as shown in Table $1 .^{5}$ Theoretically, households still exist about $36 \%$ of inefficiency that they may improve. These scores are used as the dependent variable for the efficiency model

2 This variable associated with income diversification was calculated by the Simpson index of diversity (Hill, n.d.). This index of income diversity $=\sum_{i=1}^{N=6} P_{i}^{2}$

$\sum_{i=1}^{N=6} P_{i}^{2}=\left(\frac{I_{1}}{I_{T}}\right)^{2}+\left(\frac{I_{2}}{I_{T}}\right)^{2}+\left(\frac{I_{3}}{I_{T}}\right)^{2}+\left(\frac{I_{4}}{I_{T}}\right)^{2}+\left(\frac{I_{5}}{I_{T}}\right)^{2}+\left(\frac{I_{6}}{I_{T}}\right)^{2}$

$\mathrm{N}$ is the number of different income sources (6 income sources were identified) and $I_{i}$ is household income generated by income source $i^{\text {th }}$. Different income sources are total value of coffee products $\left(I_{l}\right)$, total value of paddy rice products $\left(I_{2}\right)$, income from other crops $\left(I_{3}\right)$, income from livestock $\left(I_{4}\right)$, income from agricultural services $\left(I_{5}\right)$, and income from non-agricultural activities $\left(I_{6}\right)$. $I_{T}$ represented total income of household. See (Illukpitiya \& Yanagida, 2010) for an application of this index.

3 At the break point for 80 non-poor households, Chow test result for the structural change showed a Fvalue of 0.015 and $P$ of 0.903 .

4 The largest value of VIF was 1.1 for ethnicity variable.

5 The DEA approach was applied for estimation of technical efficiency scores with application of the DEAQual excel add-in. 
as 2-step procedure. The second stage can be different types of regression. (McDonald, 2009) suggested that 2-Limit Tobit estimates for second stage of DEA are often similar to OLS estimates. In addition, the McDonald's study indicates that OLS and QMLE (quasi-maximum likelihood estimation) produce similar inferences. However, OLS is a familiar, easy to compute method, and this approach is broadly understood. For these reasons, OLS estimates are applied for this study.

From Table 2, there is at least one selected variable that governs technical efficiency of agricultural farming. In other words, about $61 \%$ of variance of technical efficiency is explained by the variance of the selected explanatory variables $(\mathrm{F}=27.88, \mathrm{P}<0.0001)$.

Income diversification is found to be negatively related to technical efficiency because the Simpson index has a positive and significant effect on production efficiency for households in the rural area in Ea Hleo. This means that households with more diverse income sources are less technically efficient in farming. This is consistent that income of non-poor household group is less significantly diverse than that of poor household group. For instance, by improving this index for a household by 0.1 , its technical efficiency may increase about 0.0568 . The results of OLS regression also indicate that majority people are not statistically more efficient than the minority.

Table 2: Determinants of technical efficiency

\begin{tabular}{|l|c|c|c|c|}
\hline Variables & Coefficients & $\begin{array}{c}\text { Standard } \\
\text { Error }\end{array}$ & $\mathbf{t}$ Value & Pr $>|\mathbf{t}|$ \\
\hline (Constant) & .432 & .095 & 4.573 & .000 \\
\hline Poor ( 1 for poor households, 0 for otherwise) & .015 & .030 & .497 & .620 \\
\hline Loan*** & .006 & .002 & 2.944 & .004 \\
\hline $\begin{array}{l}\text { Loansize (1 for loan }<10 \text { Mil. VND, 0 for } \\
\text { otherwise) ** }\end{array}$ & -.091 & .041 & -2.204 & .029 \\
\hline Ethnicity (1 for majority, 0 for otherwise) & -.048 & .031 & -1.548 & .124 \\
\hline Simpson Index *** & .568 & .067 & 8.467 & .000 \\
\hline Age & -.002 & .001 & -1.155 & .250 \\
\hline Experience & .001 & .003 & .386 & .700 \\
\hline Land ** & -.085 & .039 & -2.153 & .033 \\
\hline Labor & .000 & .000 & -.702 & .483 \\
\hline $\begin{array}{l}* * \text { statistically significant at } \alpha=95 \% \text { confident limit } \\
* \text { Statistically significant at } \alpha=90 \% \text { confident limit } \\
\text { Dependent Variable: Efficiency }\end{array}$ & & & \\
\hline $\begin{array}{l}R \text { square }=0.617 \\
F-\text { value }=27.88, P<0,0001\end{array}$ & & & \\
\hline
\end{tabular}


The results of OLS estimates shown in Table 1 also suggests that credit size has a positive and significant effect on the efficiency. This means that credit is linearly and positively related to the efficiency of farming for rural farmers in the research site. This can be explained as the loaned credit helps to mitigate financial problems that farmers may face during the production period by enabling them to purchase more of the needed

inputs. This is similar to the results obtained by (Nchare, n.d. , 2007) for the analysis of factors affecting the technical efficiency in Arabica coffee production in Cameroon (also, see Obwona, 2006). In addition, we do not find a positive effect of credit size on the households' efficiency or micro credit is not a tool to increase the efficiency of households in the study site.

It is noted that land area under cultivation measured in hectare (at $95 \%$ confident limit) negatively affects technical efficiency of farming for households in the rural area in Ea Hleo. This means that larger scale of land may lead to less efficient use of input factors. However, there is not enough confidence to conclude about the effect of age, experience, and labor on efficiency of farming for rural households in Dak Lak.

\subsection{Implication}

The findings in this paper provide some implications for rural development policies. First, it shows that land scale is negatively affecting household efficiency. Thus, single land provision to the minority ethnic households as current policy of Vietnam, while the way allocating recourses of the households is kept unchanged, may not be effective. Rural households become more and more inefficient in allocating their resources as their land scale increases. Second, income diversity is inversely related to a household efficiency in the whole sample as well as in sub-groups of the poor and non-poor. The reason is that if a household has too many income-generated activities among which resources may be inefficiently allocated. Thus, concentrating on major crops may positively improve a household efficiency because the household is able to intensively invest in those crops. Third, there is no evidence that micro-credit can improve households' efficiency. ${ }^{6}$ The efficiency is positively and significantly related to the size of loans or households know how to manage their investment in production regardless of how large it is. Thus, micro-credit programs are unlikely to contribute to poverty reduction. This finding is consistent with recent studies (Banerjeey et al., 2009; Karlan, 2012). Finally, raising technical efficiency can contribute much to a household's income simply via a better allocation of its recourses or concentration on some primary income-generated activities.

\section{Concluding Remarks}

This paper presents an economic analysis of technical efficiency among rural households in Ea Hleo district, Daklak province, where coffee and rice cultivations generate a large income share.

6 The inclusion of quadratic form of loans to the model does not improve the model as a whole. Please refer to the appendix. 
The study has showed that there is a potential to increase farming efficiency through concentration on primary income generated activities or/and better resource management practices. In addition, provision of cultivated land to rural households can be considered an inefficient policy if their current cultivation methods are kept unchanged. Furthermore, micro-credit is not a effective tool to improve households' efficiency but the provision of larger-sized loans can lead to a positive outcome. For above-mentioned reasons, a rural development program or policy should be designed in consideration of intensive cultivation practices, larger credit size and suitable land scale for rural households.

\section{References}

Balisacan, A. M., Pernia, E. M., and Estrada, G. E. B. (2003). Economic growth and poverty reduction in Vietnam. Asian Development Bank.

Banerjeey A., Esther D., Rachel G., and Cynthia K. (2009). The miracle of microfinance? Evidence from a randomized evaluation. Financial Access Initiative, New York.

Battese, G. E. and Coelli, T. J. (1995). A model for technical inefficiency effects in a stochastic frontier production function for panel data. Empirical Economics. 20(2): 325-332

Charnes, A., Cooper, W. W., and Rhodes, E. (1978). Measuring the efficiency of decision making units. European Journal of Operational Research., 2(6): 429-444.

Cinemre, H. A., Ceyhan, V., Bozoğlu, M., Demiryürek, and Kılıc, O. (2006). The cost efficiency of trout farms in the Black Sea Region, Turkey. Aquaculture, 251 (2-4): 324-332.

Hien, D. P. (2006). Factors determining the participation of poor households in advanced technology application in agricultural production. The Vietnam Journal of Socioeconomic Development, vol (NA): pp. (NA).

McDonald, J. (2009). Using least squares and tobit in second stage DEA efficiency analyses European. Journal of Operational Research, 2(1): 792-798.

McKernan, S. M. (2002). The impact of microcredit programs on self-employment profits: Do noncredit program aspects matter?. Review of Economics and Statistics, 84(1): 93-115.

Nchare, A. (2007). Analysis of factors affecting the technical efficiency of arabica coffee producers in Cameroon. African Economic Research Consortium, 38: pp. (NA).

Obwona, M. (2006). Determinants of technical efficiency differentials amongst small- and medium-scale farmers in Uganda: A case of tobacco growers. African Economic Research Consortium, 2: pp. (NA). 
24 Niem: Factors Determining the Technical Efficiency of Rural Households in Dak Lak Province of Vietnam

Pitt, M. M. and Khandker, S. R. (1998). The impact of group-based credit programs on poor households in Bangladesh: Does the gender of participants matter?. The Journal of Political Economy, 106(5): 958-995.

Seyoum, E. T., Battese, G. E. và Fleming, E. M. (1998). Technical efficiency and productivity of maize producers in eastern Ethiopia: a study of farmers within and outside the SasakawaGlobal 2000 project. Agricultural Economics, 19: 341-348. 